Article

\title{
Solar Desalination System Design for Irrigation/Drinking Water and Electricity Generation in Desert or Arid Areas
}

Jose Izquierdo, Richard E. Blanchard*

Loughborough University, Loughborough LE11 3TU, UK

* Correspondence: Richard E. Blanchard; Email: r.e.blanchard@lboro.ac.uk.

\begin{abstract}
Climate change and population growth are likely to be future challenges to obtaining water and growing crops in arid areas. Traditional hand pumps are available but give relatively low flows; they are time consuming and are limited by the depth of wells. In low latitudes, solar energy can be the main renewable energy source for water pumping and desalination. In this project, several ways to get irrigation water, drinking water and electricity have been evaluated in the country of Western Sahara. Solar pumps have been proven to be a reliable economic solution for irrigation, but drinkable water is also required in arid areas where the salinity of water wells can be high. There is an obvious synergy when using photovoltaic solar panels for pumping, desalination, and electricity generation, but the feasibility of a project involving all those uses depends on demand and finance. This paper uses resource, technology, and economic assessments to model scenarios that demonstrate the viability of this triple approach. A Net Present Value of €26,887, and an Internal Rate of Return of $10.41 \%$ was found where $7 \mathrm{~m}^{3}$ of water was pumped per day.
\end{abstract}

KEYWORDS: solar pumps; irrigation; drinking water; PV; reverse osmosis desalination; sustainable development

\section{G Open Access}

Received: 03 October 2019

Accepted: 27 March 2020

Published: 30 March 2020

Copyright $\odot 2020$ by the author(s). Licensee Hapres, London, United Kingdom. This is an open access article distributed under the terms and conditions of Creative Commons Attribution 4.0 International License.

\section{NOMENCLATURE}

$A_{p v}$, effective area of the PV array; $E_{e}$, daily energy demand; $E_{T}$, required energy; $F_{t h}$, thermal factor; $G_{r e f}$, reference irradiance; GIWR, Gross Irrigation Water Requirement; $H_{T}$, daily solar radiation on the PV array surface; IRR, Internal Rate of Return; $\eta_{b}$, battery efficiency; $\eta_{i n v}$, inverter efficiency; $\eta_{p}$, water pump efficiency; $\eta_{p v}$, measured efficiency of the PV array; NPV, Net Present Value; $\eta_{\text {ref }}$, efficiency of the PV array under standard test conditions; PR, Performance Ratio; PV-BWRO, photovoltaic brackish water reverse osmosis; PSSH, Peak sunshine hours; SADR, Sahrawi Arab Democratic Republic; $T_{\text {ref }}$, Reference cell temperature 


\section{INTRODUCTION}

Around 1/3 of the Earth's land surface is desert, and access to water is one of the main problems for many communities in these areas. Climate change and population growth are putting pressure on resources and the ability to meet Sustainable Development Goal 6 for clean water. In general, water is required for drinking, cooking and washing as well as for livestock and irrigation of crops. Irrigation in dry areas is a challenge because of efficiency requirements and the salinity of water. Some of the main solutions to tackle the salt water issue are farming salt tolerant crops and using desalination systems. Traditionally, the extraction of water in desert areas has been made with manual or diesel pumps. However, the use of solar pumps could be ideal due to high irradiance levels in these areas and the relationship between demand and resource. In addition, diesel fuel supply would not be a limitation.

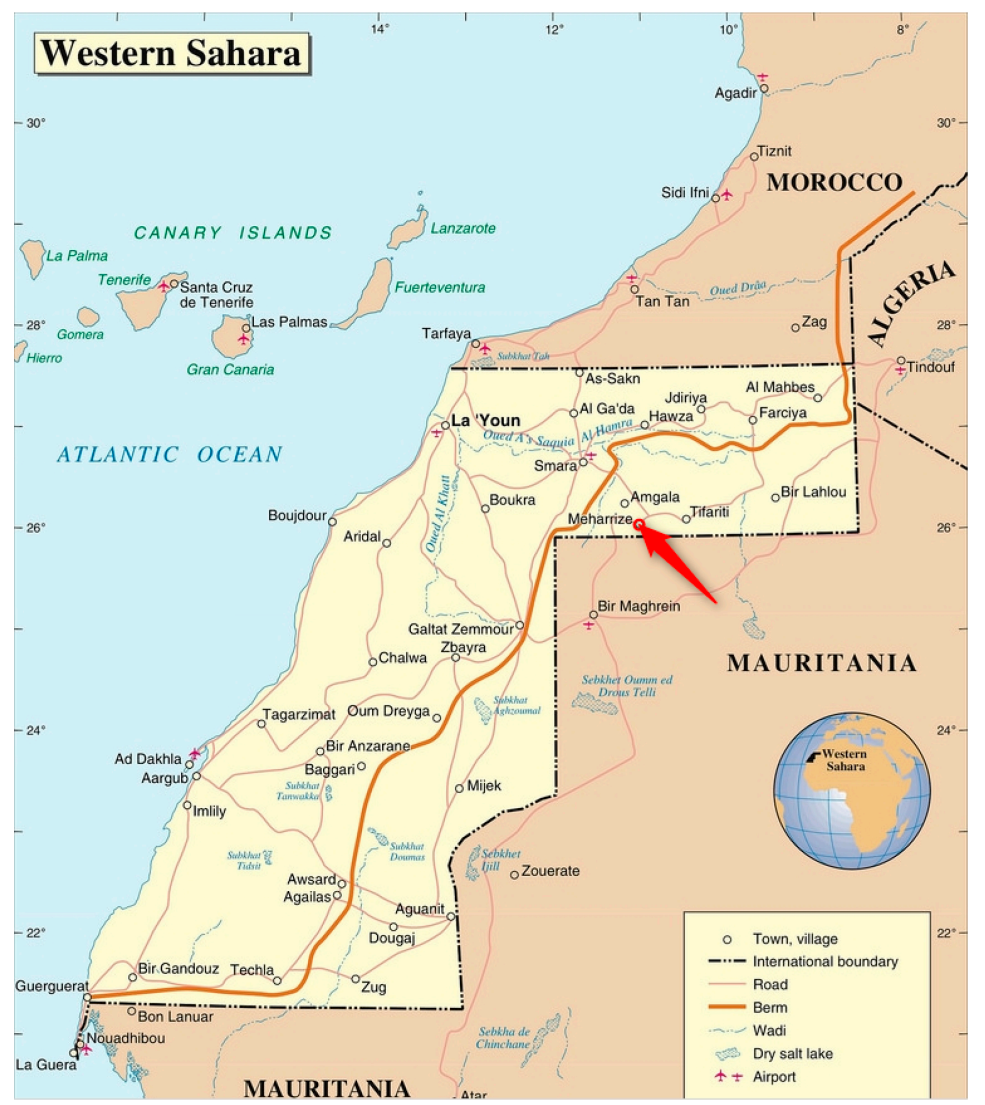

Figure 1. Map of Western Sahara with project location indicated at Coordinates: 26.172147, -11.0875829. Source: http://www.un.org/Depts/Cartographic/map/profile/wsahara.pdf. Accessed 2019 Oct 1.

The territories of Western Sahara controlled by SADR (Sahrawi Arab Democratic Republic) are considered particularly interesting for developing solar pumping projects for irrigation. There are many instances of crop farming in desert areas, but in the selected area there is no agricultural tradition. Therefore, there is potential for helping local people to grow food and obtain potable water with a reasonable investment. The selected location is a smallholding close to Meharrize 
(also known as Mehaires) where a borehole has already been drilled and there are two existing diesel pumps. There is no access to the electricity grid, and water from the well is considered salty, measured at 10,000$12,000 \mathrm{ppm}$. Drinkable water can be obtained in Meharrize, but when the river is dry it needs to be purchased, which is very expensive. The location of the project is shown in Figure 1.

\section{Aim and Objectives}

The aim of this project was to design and to evaluate the feasibility of a system to provide water and electricity in desert areas using solar pumps and PV power.

The objectives of the project were:

- To undertake an assessment of water and energy resources in the specific desert area.

- Based on this assessment, to identify suitable technologies for water pumping, desalination and electricity generation at the location.

- To ascertain the water and energy needs in the selected area.

- To design a solar desalination and electricity generation system to provide water and power.

- To perform an economic analysis of the model.

- To perform an economic sensitivity analysis of the model.

\section{LITERATURE REVIEW}

The literature on the following topics has been reviewed: (1) solar water pump projects for irrigation in general and in deserts, including [1-10]; (2) installation details and elements of the off-grid photovoltaic (PV) system [11-13]; (3) comparison of desalination technologies [14,15]; (4) reverse osmosis (RO) with PV [16,17]; (5) quality of the water (salinity and other aspects) and guidelines for drinking water quality [18]; (6) comparisons of different systems for pumping water [19,20]; and (7) other alternatives such as using a greenhouse. This literature has been used to inform the technical review and system development.

The contribution of this project is the design of a medium scale system integrating the most appropriate elements identified by the literature for solar pump irrigation, desalination, and PV solar energy generation in the Western Sahara, an under-researched region of the world. However, the potential impact is through replicating the design in different configurations and locations depending on end-user requirements.

\section{Technical Review}

Given the solar resource data and the water available from the well at the site, the technologies for pumping have been investigated. A summary of the comparison of different pumping techniques can be found in Table 1 [21-23]. Solar thermal options are also possible, although not at the scale of the project [24]. 
The conclusion of the comparison is that taking into account the well depth, cost of fuel, installation requirements, and resources at the project location, a solar pump is the most appropriate technology. Due to the depth of the well, both the pump and motor must be submerged.

As indicated earlier, the salinity of the water is too high for direct irrigation. There are some crops with high saline resistance, but if brackish water is used to irrigate the salt concentration of the soil will increase progressively. Therefore, some desalination system is required to reduce the salinity of the water. Additionally, the demand for potable water in the area, and in desert areas in general, supports further desalination for drinking purposes.

Table 1. Comparison of pumping techniques.

\begin{tabular}{|c|c|c|}
\hline Pumping techniques & Advantages & Disadvantages \\
\hline Hand pumps & $\begin{array}{ll}\text { - } & \text { No fuel cost } \\
\text { - } & \text { They can be manufactured locally } \\
\text { - } & \text { Low capital costs } \\
\text { - } & \text { Easy to maintain } \\
\end{array}$ & $\begin{array}{ll}\text { - } & \text { Low flow rates } \\
\text { - } & \text { Limitations with boreholes } \\
\text { - } & \text { Time consuming } \\
\text { - } & \text { Regular maintenance needed } \\
\end{array}$ \\
\hline Animal driven pumps & $\begin{array}{l}\text { - } \quad \text { More powerful than humans } \\
\text { - } \quad \text { Animals' time is less valuable than humans' }\end{array}$ & $\begin{array}{ll}\text { - } & \text { Feeding requirements } \\
\text { - } & \text { Interference with other activities }\end{array}$ \\
\hline Diesel/gasoline pumps & $\begin{array}{ll}\text { - } & \text { Low capital costs } \\
\text { - } & \text { Easy installation } \\
\text { - } & \text { Widely used }\end{array}$ & $\begin{array}{ll}\text { - } & \text { Fuel supply } \\
\text { - } & \text { Pollution and noise } \\
\text { - } & \text { High maintenance costs } \\
\text { - } & \text { Relatively short life } \\
\end{array}$ \\
\hline Wind pumps & $\begin{array}{ll}\text { - } & \text { No fuel costs } \\
\text { - } & \text { Local manufacture is possible } \\
\text { - } & \text { Unattended operation } \\
\text { - } & \text { Long life } \\
\end{array}$ & $\begin{array}{ll}\text { - } & \text { High capital costs } \\
\text { - } & \text { Storage is needed (for low wind periods) } \\
\text { - } & \text { Not easy to install } \\
\text { - } & \text { Wind variability } \\
\end{array}$ \\
\hline Solar pumps (PV) & $\begin{array}{ll}\text { - } & \text { No fuel costs } \\
\text { - } & \text { Easy installation } \\
\text { - } & \text { Unattended operation } \\
\text { - } & \text { Low maintenance and long life }\end{array}$ & $\begin{array}{ll}\text { - } & \text { High capital costs } \\
\text { - } & \text { Storage might be needed (cloudy periods) } \\
\text { - } & \text { Repairs may require skilled technician }\end{array}$ \\
\hline
\end{tabular}

A directly coupled solar pump using solar irradiance from PV modules to power the system reduces the investment outlay by avoiding the cost of batteries. However, in this off-grid installation, there are other considerations such as the desalination unit. Therefore, a battery coupled system has to be utilized, thus allowing energy consumption out of peak sun hours and into the evening.

Different technologies for desalination have also been compared, taking into account the raw water quality (salinity), the product quality, water flows, energy consumption, and maintenance requirements. The desalination technologies were classified as thermally activated, pressure activated, electrically activated, chemically activated or activated through adsorption. Thermally activated systems include evaporation systems such as multiple-effect distillation (MED), multi-stage flash distillation 
(MSF), vapor compression distillation or mechanical vapor recompression (MVC), humidification-dehumidification desalination, and solar distillation (SD) systems. Crystallization systems such as freezing are also thermal techniques. Some of the main pressure-activated and electrically activated systems using permeable membranes are electro-dialysis (ED), reverse osmosis (RO), forward osmosis and nanofiltration. The most common chemically activated desalination system is ion-exchange desalination. The desalination application of adsorption technology, for example with silica gel, is relatively new [14]. MED and MSF technologies can be combined with concentrated solar power (CSP). A comparison of some of the main desalination techniques can be found in Table 2, from [14,15,21-23].

Table 2. Comparison of desalination technologies [14,15,21-23].

\begin{tabular}{|l|c|c|c|c|c|}
\hline & MED/CSP-MED & MSF/CSP-MSF & MVC & ED & RO \\
\hline Activation/driving force & $\begin{array}{c}\text { Thermally } \\
\text { activated }\end{array}$ & $\begin{array}{c}\text { Thermally } \\
\text { activated }\end{array}$ & $\begin{array}{c}\text { Thermally } \\
\text { activated }\end{array}$ & $\begin{array}{c}\text { Electrical } \\
\text { Potential }\end{array}$ & Pressure activated \\
\hline Raw water quality & Not critical & Not critical & Not critical & $<10000 \mathrm{ppm}$ & Pre-treatment needed \\
\hline $\begin{array}{l}\text { Product quality } \\
\text { (ppm of TDS) }\end{array}$ & $<20 \mathrm{ppm}$ & $<20 \mathrm{ppm}$ & $<20 \mathrm{ppm}$ & $150-500 \mathrm{ppm}$ & $\begin{array}{c}200-500 \mathrm{ppm}(1 \mathrm{stage}) \\
10-50 \mathrm{ppm}(2 \mathrm{stages})\end{array}$ \\
\hline Heat consumption $\left(\mathrm{MJ} / \mathrm{m}^{3}\right)$ & $145-230$ & $190-300$ & NA & NA & NA \\
\hline $\begin{array}{l}\text { Power consumption } \\
\left(\mathrm{kWh} / \mathrm{m}^{3}\right)\end{array}$ & $<2.5$ & $2.5-5$ & $7-12$ & $1.5-5.5$ & $3-6 *$ \\
\hline Maintenance cost & Low & Low & Low & Low & Medium \\
\hline
\end{tabular}

* See clarification below in the main text about typical consumptions from using SW and BW.

The conclusion of the comparison of different desalination technologies shown in Table 2 is that Reverse Osmosis (RO) is the most appropriate technology for this small/medium scale application. For brackish water of less than 5000 ppm TDS (total dissolved solids), electro-dialysis (ED) could be more appropriate, but the salinity of the raw water in this case $(10,000$ $12,000 \mathrm{ppm}$ ) is too high for ED [25]. The salinity range is appropriate for $\mathrm{RO}$. The average power consumption of RO is higher than for some other technologies (using heat) and more maintenance may be needed, but the investment and consequent water production cost for RO is typically lower. The technology is commonly used, and there are commercial portable units on the market. According to [25-28], RO typically consumes 3-10 kWh to produce $1 \mathrm{~m}^{3}$ of fresh water from seawater (SWRO), but typically consumes only $0.5-2.5 \mathrm{kWh} / \mathrm{m}^{3}$ to produce fresh water from brackish water (BWRO), depending on the dissolved salt-the concentration of salt in seawater is normally 30,000-50,000 ppm (typically $35,000 \mathrm{ppm}$ ), whereas the concentration of salt in brackish water is normally between 1000 and 35,000 ppm (mildly 1000-5000 ppm, moderately 5000-15,000 ppm, heavily 15,000-35,000 ppm).

The selected scheme can be denominated a PV-BWRO system because it combines PV and BWRO technologies. It is possible to design a PV-RO 
system without batteries (as in [16]) to reduce costs, but it makes the design more complicated and the system less flexible.

\section{Water Requirements}

In order to determine the agricultural water needs, the irrigation water requirements (IWR) have been estimated. IWR depends on the cropping pattern and the climate. According to [29], in the selected location the net irrigation water requirement (NIWR) is $1250 \mathrm{~mm} / \mathrm{year}$, and the gross irrigation requirement (GIWR) is $1800 \mathrm{~mm} /$ year. An irrigation cropping pattern of vegetables from February to November, wheat and fodder from October-November to April-May, and arboriculture all year has been considered. Assuming equal distribution during the year, $49.3 \mathrm{~m}^{3} /$ day/ha is needed.

$$
\text { GIWR }=\frac{1800 \mathrm{~mm}}{365 \text { days }} \times \frac{10 \frac{\mathrm{m}^{3}}{\mathrm{ha}}}{1 \mathrm{~mm}}=49.3 \frac{\mathrm{m}^{3} / \text { day }}{\mathrm{ha}}
$$

An efficiency E lower than 70\% has been assumed (GIWR $=$ NIWR/E). However, with drip irrigation the efficiency can be increased to $95 \%$, thus reducing the required value to $36.3 \mathrm{~m}^{3} / \mathrm{day} / \mathrm{ha}$. Drip irrigation is suitable for row crops (e.g., vegetables, soft fruit, trees, and vines). The water requirements must be adjusted depending on the type of crop and the estimated requirements for each month. Water requirements could be reduced with a greenhouse. Considering an area of $1050 \mathrm{~m}^{2}$ (e.g., $30 \mathrm{~m} \times$ $35 \mathrm{~m}$ ) or $0.1 \mathrm{ha}$, the water required for irrigation is $3.8 \mathrm{~m}^{3}$. For an area of $2500 \mathrm{~m}^{2}(50 \mathrm{~m} \times 50 \mathrm{~m})$ or $0.25 \mathrm{ha}$, the required water for irrigation is around $9 \mathrm{~m}^{3} /$ day. If the water requirements are reduced, then the area can be extended. Regarding potable water, a flow of $2 \mathrm{~m}^{3} /$ day should be enough for 50 people if the consumption is $40 \mathrm{~L}$ /day per person (for diverse uses). The methods used are now considered.

\section{METHODOLOGY}

A description of the methodology employed in this project is now detailed.

- First, an assessment was performed to identify the solar irradiance and water resources in the project area. Solar irradiance data was obtained from several sources [30-32]. For water resources, a water survey allowed for an understanding of the limitations on and difficulties involved in obtaining water at the required quality. Water was sampled and analysed to determine the salinity and other characteristics (performed by local contact).

- Subsequently, appropriate technologies for water pumping, desalination and electricity generation were reviewed. 
o Water pumping:

(a) Pumping techniques: hand pumps, animal driven pumps, diesel/gasoline pumps, wind pumps, solar pumps.

(b) Types of pumps: centrifugal, positive displacement or other type; directly coupled (battery-free) or battery coupled; AC or DC.

(c) Motor and pump configuration: submerged motor-pump set, submerged pump with surface motor, floating motor-pump set, surface motor-pump set [1].

o Desalination: different technologies were compared, including thermal, pressure activated, chemically activated and adsorption. This comparison considered the salinity of the intake flow, the output salinity requirements, water flows and energy consumption $[14,23,24]$.

o Electricity generation in general: diesel generation, wind, solar PV and grid connection.

- The next step was to prepare the first draft of desired or expected requirements, considering different scenarios and the main needs of the project area. The variables considered were water flow for irrigation and potable water and the number of dwellings for power consumption. Eight scenarios were scoped out for the initial evaluation, with the purpose of selecting between 1 and 3 of them for more detailed calculation and economic analysis. There was some flexibility in scale of the design, depending on economic viability, because there is interest in living in the neighbourhood, currently an underdeveloped area (Douh pers com). Thus, the number of dwellings was one of the variables. The PV modules were considered for solar pump irrigation and other possible electrical consumption, including water desalination. In order to estimate the water consumption and the technology to be used, it was necessary to determine the number of people consuming water, the variety of crops (e.g., high salinity tolerant plants), and the crop growth and/or greenhouse area. There was also flexibility for expanding the crop area beyond the initial 1 ha. This requirements capture could be applied to other dry area communities.

- A diagram of the scheme was drafted in AutoCAD, including the main equipment and elements of the system. Two methods were considered for different farming solutions, namely open irrigation and a greenhouse.

- Then the system model was produced, incorporating all the components and devices, the resources available and the requirements captured. Preliminary calculations were made to assess the efficacy of the system.

- The model was then tested to verify that the variables could be changed, and it was giving satisfactory results. The model was implemented in Excel. The PV and pump calculations were double 
checked and verified with the PVsyst software package [32]. Several scenarios were considered, with variations on irrigation and potable water consumption as well as the number of dwellings consuming electricity.

- With the main design developed, further detailed engineering was completed with the definition of all equipment (tanks, desalination), devices (panels, controller, regulator, batteries), and variables/dimensions (heights, lengths, tanks, piping) in order to more precisely specify the elements of the system with the costs assessed as well.

- An economic analysis was performed, including the life cycle costs, payback, and net present value calculations.

- Finally, a sensitivity analysis of the model was investigated to show the impact of changing variables; notably, the discount rate, the inflation rate, the fuel cost and the water cost. The results are now presented.

\section{RESULTS AND DISCUSSION}

A system capable of providing electricity and water for both drinking and irrigation has been designed. The only resources needed to operate the system are the sun and brackish water from a well in a desert area. Financially, there is a moderate investment that can be recovered. Additionally, different water flow rates and electricity production for one or several dwellings have been modelled.

\section{Resource Assessment}

For the solar irradiance, the most appropriate data identified was from [31]. According to the water analysis carried out, the salinity was around $11 \mathrm{~g} / \mathrm{L}$ (between 10,000 and 12,000 ppm or $17 \mathrm{dS} / \mathrm{m}$ ) (an electrical conductivity EC $=17 \mathrm{dS} / \mathrm{m}$ has been measured. A conversion $1 \mathrm{dS} / \mathrm{m} \rightarrow 640$ $\mathrm{mg} / \mathrm{L}$, from EC to TDS (total dissolved salts) has been applied), which means that the water was brackish water (BW). This value has been used for the basic design of the desalination unit, but once the plant designed in this study is operational samples would have to be tested regularly. The condition of aquifers and soil quality have been checked from several sources such as [33]. According to the consulted sources, the aquifer in the selected location seems to be between sedimentary and basement fracture, and the productivity is low. The risk of water table recession should be assessed if possible, but the well should be considered to be reliable. Because there is flexibility in the requirements of water and electricity, as indicated above, several scenarios have been considered, changing the variables (water flow for irrigation, drinking water, number of dwellings), as shown in Table 3. 
Table 3. Scenarios (cases).

\begin{tabular}{|c|c|c|c|c|c|c|}
\hline \multirow[b]{2}{*}{ Cases } & \multirow{2}{*}{$\begin{array}{c}\text { Pumping } \\
\left.\text { flow ( } \mathrm{m}^{3} / \text { day }\right)\end{array}$} & \multicolumn{2}{|c|}{ Desalination flow for: } & \multirow{2}{*}{$\begin{array}{l}\text { Brine } \\
\text { flow }\end{array}$} & \multirow{2}{*}{$\begin{array}{c}\text { Dwellings } \\
\text { (\#) }\end{array}$} & \multirow[b]{2}{*}{ Description Cases } \\
\hline & & $\begin{array}{c}\text { Irrigation (I) } \\
\left(\mathrm{m}^{3} / \text { day) }\right.\end{array}$ & $\begin{array}{c}\text { Drinking (D) } \\
\left(\mathrm{m}^{3} / \text { day) }\right.\end{array}$ & & & \\
\hline Case 0 & 7 & 0 & 0 & 0 & 0 & Only pumping, no desalination \\
\hline Case 1 & 7 & 6 & 0 & 1 & 0 & Only irrigation, no drinking water \\
\hline Case 2 & 7 & 4 & 2 & 1 & 0 & Irrigation (I) \& drinking (D), medium flow \\
\hline Case 3 & 7 & 4 & 2 & 1 & 1 & I \& D, medium flow and 1 dwelling \\
\hline Case 4 & 7 & 4 & 2 & 1 & 4 & I \& D, medium flow and 4 dwellings \\
\hline Case 5 & 12.8 & 9 & 2 & 1.8 & 0 & Irrigation (I) \& drinking (D), higher flow \\
\hline Case 6 & 12.8 & 9 & 2 & 1.8 & 1 & I \& D, higher flow and 1 dwelling \\
\hline Case 7 & 12.8 & 9 & 2 & 1.8 & 4 & I \& D, higher flow and 4 dwellings \\
\hline
\end{tabular}

\section{System Diagram}

The main equipment and elements required for the system are shown in Figure 2.

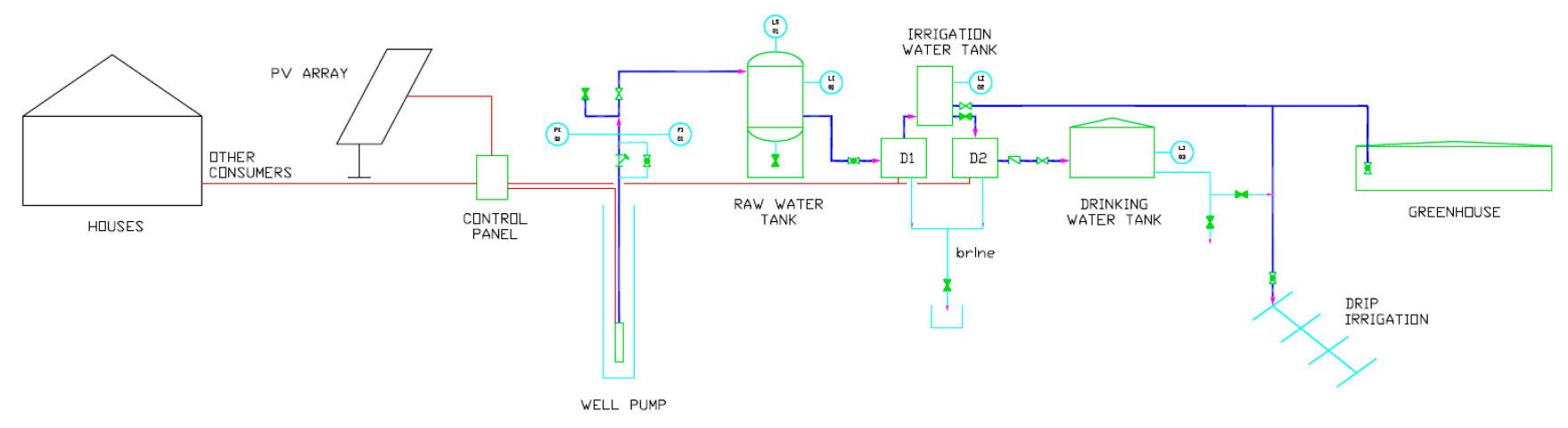

Figure 2. Diagram of the PV-BWRO system.

The PV array is generating electricity that will be managed by the control panel. The elements of the panel are detailed in Figure 3. The well pump is powered and controlled from this panel. The other electrical uses are the desalination units (D1 and D2) and the potential additional consumers in the houses or dwellings. The well pump sends water to the Raw Water (RW) tank. There is a filter (with a bypass) at the discharge of the pump in order to retain the waste, and valves can pump to other locations if needed. The RW tank is at higher elevation to feed the first stage of the RO Desalination (D1), which reduces the salinity. This system provides irrigation water, which is stored in the Irrigation Water (IW) tank. The IW can drip feed the irrigation system or the greenhouse, if applicable. The salinity will be further reduced to acceptable levels for potable water in the second stage of desalination (D2). The brine flowing from both desalination units are routed to a tray, basin or pit big enough to store water for several days given the evaporation rates. Several compartments can be built to facilitate salt production for other uses. The salts should be analysed regularly depending on the use. The fresh water 
from the second stage of desalination (D2) is stored in the Drinking Water (DW) tank. A pipe connection with a manual valve (and with a check/nonreturn valve) can be included in order to dilute the irrigation water to the drip irrigation system. RO typically requires some pre-treatment, mainly filtration, and a well pump discharge filter can be enough. The depths and levels of the system have been represented in Figure 4 [19,21].

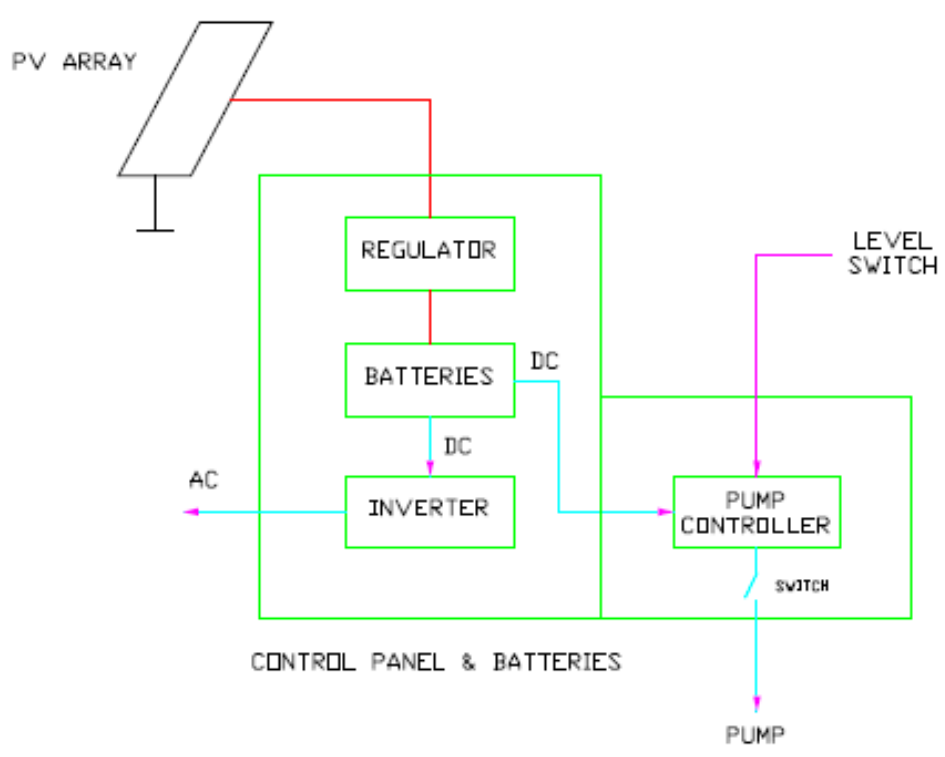

Figure 3. Control panel \& batteries schematic.

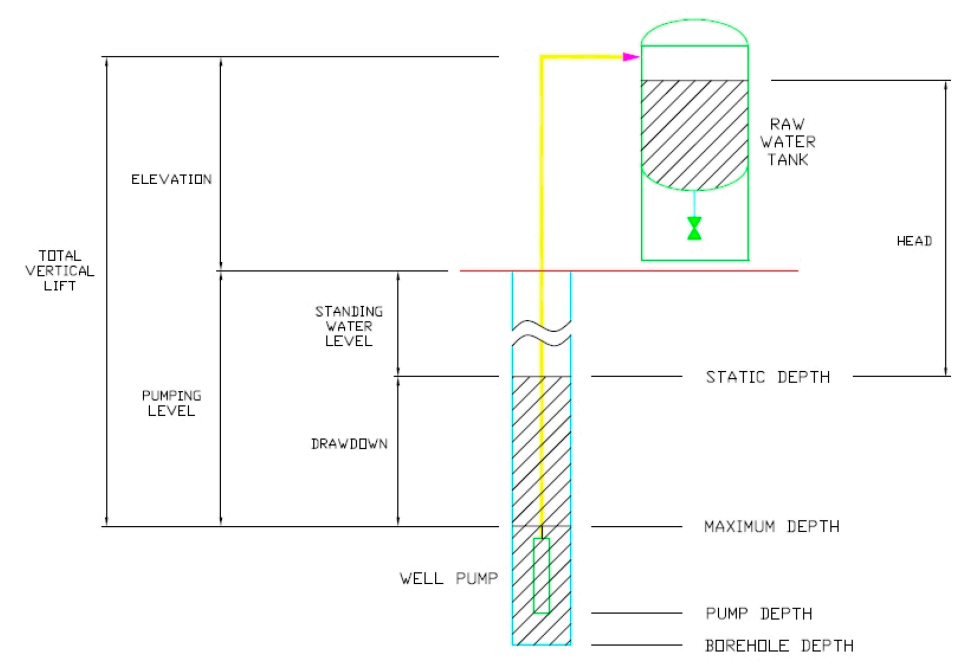

Figure 4. Submerged pump vertical lift diagram.

\section{System Model}

Based on this scheme, a model has been developed in Excel for hydraulic and mass balance calculations and the calculation of the PV array size. Furthermore, the detailed PV calculations have been validated with PVsyst [32], producing similar results.

The model has been tested with all the scenarios. However, only three of them have been selected for further analysis: Case 2 (base case), Case 3 
and Case 6. Case 0 is not relevant in this situation because the salinity of the water is too high for irrigation, and desalination is needed. Drinking water must be considered, so Case 1 is only illustrative. Cases 4 and 7 (with 4 dwellings) have not been considered for a first phase of implementation because the cost would be is higher, and the dwellings have not yet been constructed. Only one dwelling has been considered (in Cases 3 and 6) for the people taking care of the crops.

\section{Water and Solar Calculations}

The existing borehole is $50 \mathrm{~m}$ deep. However, water is already present at $20 \mathrm{~m}$, according to the local contact. But it has been estimated based on experience that the water flow can be higher if the well is drilled deeper. For hydraulic calculations, a depth of $75 \mathrm{~m}$ has been assumed, but a total head $\mathrm{H}$ of $100 \mathrm{~m}$ has been used to include the pressure drops of the system and to allow for some margin. The flow rate is dependent on the case (volume per day and number of hours pumping). In Case $2,7 \mathrm{~m}^{3}$ are pumped per day. Taking $5 \mathrm{~h}$ per day on average (this value is lower than the peak sunshine hours PSSH: 5.9. In reality, the system will pump for longer with lower flow rate. This fact is relevant for calculating the design flow rate and the power, but it does not affect the Energy calculation), the flow rate $\mathrm{Q} 1.4 \mathrm{~m}^{3} / \mathrm{h}$. The estimated density $\rho$ for $12 \mathrm{~g} / \mathrm{L}$ at $20{ }^{\circ} \mathrm{C}$ is $1007 \mathrm{~kg} / \mathrm{m}^{3}$; and the gravitational acceleration $\mathrm{g}$ is $9.81 \mathrm{~m} / \mathrm{s}^{2}$. From Equation (1), the hydraulic power is $0.384 \mathrm{~kW}$, and considering a pump efficiency $\eta_{p}$ of 0.75 , the required power is $0.512 \mathrm{~kW}$. Therefore, the energy required for pumping $7 \mathrm{~m}^{3}$ is $2.56 \mathrm{kWh}$. This value can be also calculated directly from Equation (2) without defining the number of pumping hours per day.

$$
\begin{gathered}
\qquad \text { Power }[W]=Q\left[\mathrm{~m}^{3} / \mathrm{s}\right] \times \rho\left[\mathrm{kg} / \mathrm{m}^{3}\right] \times g\left[\mathrm{~m} / \mathrm{s}^{2}\right] \times H[\mathrm{~m}] \\
\text { Energy required for pumping }[\mathrm{kWh} / \text { day }]=\frac{Q\left[\mathrm{~m}^{3} / \mathrm{day}\right] \times \rho\left[\mathrm{kg} / \mathrm{m}^{3}\right] \times g\left[\mathrm{~m} / \mathrm{s}^{2}\right] \times H[\mathrm{~m}]}{\eta \times 3600[\mathrm{~s} / \mathrm{h}] \times 1000[\mathrm{~W} / \mathrm{kW}]}
\end{gathered}
$$

For the basic design of the RO unit, two stages have been considered. In the 1st stage, the salt concentration is reduced from $11 \mathrm{~g} / \mathrm{L}$ to $1 \mathrm{~g} / \mathrm{L}$ (1000 ppm). This water is used for irrigation. The inlet of the 2nd stage is not the brine but the partially desalinated water stream. In the 2nd stage the concentration is reduced from $1 \mathrm{~g} / \mathrm{L}$ to $0.2 \mathrm{~g} / \mathrm{L}$ (200 ppm). A concentration of $75 \mathrm{~g} / \mathrm{L}$ (typically $50-75 \mathrm{~g} / \mathrm{L}$ ) has been assumed for the brine. From the balance, $4.03 \mathrm{~m}^{3} /$ day of irrigation water, $2 \mathrm{~m}^{3} /$ day of potable water and about $0.97 \mathrm{~m}^{3} / \mathrm{h}$ of brine are produced. It should be noted that the brine flow produces $72.5 \mathrm{~kg}$ salt per day. This salt can have an added value, but it needs to be analysed and properly treated. Assuming a consumption of $2 \mathrm{kWh} / \mathrm{m}^{3}$ for 1 st stage (11 g/L to $1 \mathrm{~g} / \mathrm{L}$ ) and 1 $\mathrm{kWh} / \mathrm{m}^{3}$ for 2 nd stage ( $1 \mathrm{~g} / \mathrm{L}$ to $200 \mathrm{ppm}$ ), the energy to generate $4 \mathrm{~m}^{3} / \mathrm{day}$ of irrigation water and $2 \mathrm{~m}^{3} /$ day of drinking water is $14.07 \mathrm{kWh} /$ day. Therefore, the required energy $E_{T}$ for both pumping and desalination is $16.63 \mathrm{kWh} /$ day. 
The monthly averaged insolation incident on an equator-pointed tilted surface has been obtained from [16], as shown in Table 4. During the winter months, the solar irradiance is much lower, but the water consumption will be also considerably lower because no irrigation is required. With a fixed tilt of $24.6^{\circ}$ (optimum angle), the annual average insolation $H_{T}$ will be above $5.94 \mathrm{kWh} / \mathrm{m}^{2} /$ day, which is the figure for a tilt of $26^{\circ}$ (same as latitude) and this value has been used for the calculations. Solar irradiance could be optimized with a solar tracking system, to adjust the angle as required. The irradiance is similar to that found in a study in Mexico that also highlighted the use of PV for brackish water desalination [17].

Table 4. Monthly averaged insolation incident on an equator-pointed tilted surface $\left(\mathrm{kWh} / \mathrm{m}^{2} /\right.$ day).

\begin{tabular}{lcccccccccccccc}
\hline Lat 26.172/Lon-11.088 & Jan & Feb & Mar & Apr & May & Jun & Jul & Aug & Sep & Oct & Nov & Dec & Annual Average \\
\hline SSE HRZ & 3.81 & 4.68 & 5.89 & 6.98 & 7.39 & 7.56 & 7.35 & 6.80 & 5.87 & 4.83 & 3.95 & 3.38 & 5.71 \\
K & 0.58 & 0.60 & 0.63 & 0.66 & 0.66 & 0.66 & 0.65 & 0.64 & 0.61 & 0.59 & 0.57 & 0.55 & 0.62 \\
Diffuse & 1.09 & 1.28 & 1.48 & 1.65 & 1.86 & 1.93 & 1.93 & 1.83 & 1.68 & 1.43 & 1.16 & 1.07 & 1.53 \\
Direct & 5.56 & 6.14 & 7.07 & 7.92 & 8.00 & 8.13 & 7.83 & 7.26 & 6.48 & 5.88 & 5.49 & 4.90 & & 6.72 \\
Tilt 0 & 3.71 & 4.65 & 5.82 & 6.84 & 7.36 & 7.53 & 7.32 & 6.76 & 5.79 & 4.79 & 3.83 & 3.30 & & 5.65 \\
Tilt 11 & 4.29 & 5.20 & 6.21 & 6.98 & 7.22 & 7.28 & 7.13 & 6.77 & 6.04 & 5.24 & 4.37 & 3.84 & & 5.88 \\
Tilt 26 & 4.88 & 5.69 & 6.44 & 6.84 & 6.71 & 6.62 & 6.55 & 6.47 & 6.11 & 5.62 & 4.90 & 4.40 & & 5.94 \\
Tilt 41 & 5.19 & 5.88 & 6.33 & 6.34 & 5.87 & 5.64 & 5.65 & 5.84 & 5.87 & 5.69 & 5.16 & 4.72 & & 5.68 \\
Tilt 90 & 4.21 & 4.30 & 3.77 & 2.76 & 2.04 & 1.81 & 1.90 & 2.36 & 3.17 & 3.92 & 4.06 & 3.93 & & 3.18 \\
OPT & 5.24 & 5.88 & 6.45 & 6.98 & 7.36 & 7.53 & 7.32 & 6.79 & 6.13 & 5.71 & 5.19 & 4.78 & & 6.28 \\
OPT ANG & 50.0 & 42.0 & 29.0 & 13.0 & 0.00 & 0.00 & 0.00 & 6.00 & 22.0 & 37.0 & 47.0 & 51.0 & 24.6 \\
\hline
\end{tabular}

Note: Diffuse radiation, direct normal radiation and tilted surface radiation are not calculated when the clearness index (K) is below 0.3 or above 0.8 .

The size of the PV array can be calculated from the following Equations [19]. The efficiency of the pump can be included in the subsystem efficiency $\eta_{s}$. In this case, $\eta_{p}$ already has been considered, and $\eta_{s}$ is the efficiency of the subsystem from the PV array to the pump and consumers, including the batteries and inverter for AC (alternating current). A subsystem efficiency $\eta_{s}$ of 0.80 has been assumed, so the daily energy demand $E_{e}$ is $20.79 \mathrm{kWh}$ (from Equation (3)).

$$
\begin{gathered}
E_{e}=\frac{E_{T}}{\eta_{s}} \\
E_{e}[k W h]=A_{p v}\left[m^{2}\right] \times H_{T}\left[\mathrm{kWh} / \mathrm{m}^{2}\right] \times \eta_{p v} \\
P[W p]=A_{p v} \times G_{r e f} \times \eta_{r e f}=1000\left[\frac{W}{m^{2}}\right] \times A_{p v} \times \eta_{r e f}
\end{gathered}
$$

$A_{p v}$ is the effective area of the PV array in $\mathrm{m}^{2} ; G_{r e f}$ is the irradiance of reference $\left(G_{\text {ref }}=1000 \mathrm{~W} / \mathrm{m}^{2}\right)$ (the solar irradiance $\mathrm{G}$ in $\mathrm{W} / \mathrm{m}^{2}$ is the total radiative power density incident on a collector. The solar irradiation $\mathrm{H}$ in 
$\mathrm{kWh} / \mathrm{m}^{2}$ is the total radiative energy received by a collector in a specified time); $=H_{T}$ is the daily solar radiation on the PV array surface $\left(H_{T}=\right.$ $5.94 \mathrm{kWh} / \mathrm{m}^{2}$ ), or daily irradiation (some references, such as [11], use $\mathrm{G}_{\mathrm{T}}$ instead of $\mathrm{H}_{\mathrm{T}}$ in Equation (6), but the units are $\mathrm{kWh} / \mathrm{m}^{2}$ ); $\eta_{p v}$ is the efficiency of the PV array under operating conditions. The Standard Test Condition (STC) efficiency or efficiency of reference $\eta_{\text {ref }}$ is the efficiency of the PV array measured with the irradiance of reference $G_{r e f}$ and angle of incidence of zero, a solar spectrum of AM1.5 and a cell temperature $T_{\text {ref }}$ $\left(T_{r e f}=25^{\circ} \mathrm{C}\right)$ - The closest known climatic data is from Smara, which has temperatures ranging from $11-37^{\circ} \mathrm{C}$. The system is modelled on STC of $25^{\circ} \mathrm{C}$, but higher temperatures will reduce the output, depending on the PV module material. For example, with large polycrystalline modules the loss is approximately $0.25 \%$ per $1^{\circ} \mathrm{C}$ rise.

From Equations (4) and (5),

$$
\begin{gathered}
P[W p]=1000\left[\frac{W}{m^{2}}\right] \frac{E e[k W h] \times \eta_{r e f}}{H_{T}\left[\frac{k W h}{m^{2}}\right] \times \eta_{p v}} \\
P R=\frac{\eta_{p v}}{\eta_{r e f}} \\
P[W p]=1000\left[\frac{W}{m^{2}}\right] \frac{E e[k W h]}{H_{T}\left[\frac{k W h}{m^{2}}\right] \times P R}
\end{gathered}
$$

PR is the quality indicator Performance Ratio (the performance ratio is the difference between the electric generated by the PV modules and that delivered by the system taking into account system losses), calculated from $\eta_{p v}$ and $\eta_{r e f}$ (alternative notation is also commonly used: $\eta_{o p}$ (operating efficiency) instead of $\eta_{p v}$ and $\eta_{S T C}$ (standard conditions efficiency) instead of $\eta_{\text {ref }}$ or $\eta_{r}$ ).

If $\mathrm{PR}$ is 0.85 (typically $0.80-0.90$ ), then the $\mathrm{PV}$ array power $\mathrm{P}$ is $4.12 \mathrm{kWp}$ (from Equation (8)).

From Equation (4), if the conversion efficiency $\eta_{p v}$ is 0.14 , then the estimated area $A_{p v}$ of the modules is $25 \mathrm{~m}^{2}$.

In contrast to Equations (6) and (8), some authors use the PSSH (peak sunshine hours) instead of the irradiation $H_{T}$ (the figure of "peak sunshine hours” PSSH (or peak sun hours) is numerically identical to the average daily solar insolation (or irradiation). A peak sun hour is an hour when the intensity of the sunshine reaches $1 \mathrm{~kW} / \mathrm{m}^{2}$. It can be visually explained as converting the area under the curve "solar radiation vs time" in a square $1 \mathrm{~kW} / \mathrm{m}^{2} \times \mathrm{PSSH}(\mathrm{h})$ ), the mismatch or thermal factor $F_{t h}$ and the efficiency of the main elements in the system.

$$
E_{T}[k W h]=P_{\text {peak }}[k W p] \times P S S H[h] \times F_{t h} \times \eta_{b} \times \eta_{\text {inv }}
$$

If $\mathrm{PSSH}$ is $5.94 \mathrm{~h}, F_{t h}$ is 0.83 , the battery efficiency $\eta_{b}$ is 0.90 and the inverter efficiency $\eta_{\text {inv }}$ is 0.90 , then the $\mathrm{PV}$ array power $\mathrm{P}$ is $4.16 \mathrm{kWp}$ (from Equation (9)).

Similar calculations have been performed with PVSyst for all cases, getting comparable results, which have been summarized in Table 5. 
$1 \quad$ Table 5. Summary of results for cases 0 to 7.

\begin{tabular}{|c|c|c|c|c|c|c|c|c|c|c|c|c|c|}
\hline \multirow{2}{*}{ CASES } & \multirow{2}{*}{$\begin{array}{l}\text { Pumping } \\
\left(\mathrm{m}^{3} / \text { day }\right)\end{array}$} & \multicolumn{2}{|c|}{ Desalination for } & \multirow{2}{*}{$\begin{array}{c}\text { brine } \\
\left(\mathrm{m}^{3} / \text { day }\right)\end{array}$} & \multirow{2}{*}{$\begin{array}{c}\text { dwellings } \\
\#\end{array}$} & \multirow{2}{*}{$\begin{array}{l}\text { DESCRIPTION } \\
\text { CASES }\end{array}$} & \multirow{2}{*}{$\begin{array}{c}\text { Excel } E_{T} \\
\text { Energy } \\
\text { Tot } \\
\text { kWh/day }\end{array}$} & \multirow{2}{*}{$\begin{array}{c}\text { Excel P } \\
\text { Power } \\
\text { (size) } \\
\text { kWp (1) }\end{array}$} & \multirow{2}{*}{$\begin{array}{c}\begin{array}{c}\text { Excel } \\
\mathbf{A}_{\mathrm{pv}}\end{array} \\
\text { Area m }^{2} \\
\text { modules }\end{array}$} & \multirow{2}{*}{$\begin{array}{c}\text { PVsyst } \mathrm{E}_{\mathrm{T}} \\
\text { Energy Tot } \\
\text { kWh/day } \\
(2)\end{array}$} & \multirow{2}{*}{$\begin{array}{c}\text { PVsyst P } \\
\text { Power } \\
\text { (size) } \\
\text { kWp } \\
\end{array}$} & \multirow{2}{*}{$\begin{array}{c}\text { PVsyst Apv } \\
\text { Area m }^{2} \\
\text { modules }\end{array}$} & \multirow[b]{2}{*}{ PR } \\
\hline & & $\begin{array}{l}\text { irrigation } \\
\left(\mathrm{m}^{3} / \text { day }\right)\end{array}$ & $\begin{array}{l}\text { drinking } \\
\left(m^{3} / \text { day }\right)\end{array}$ & & & & & & & & & & \\
\hline CASE 0 & 7 & 0 & 0 & 0 & 0 & $\begin{array}{c}\text { Only pumping, no } \\
\text { desalination }\end{array}$ & 2.56 & 0.63 & 3.8 & 3.59 & 0.70 & 4.1 & 42.9 \\
\hline CASE 1 & 7 & 6 & 0 & 1 & 0 & $\begin{array}{c}\text { Only irrigation, no } \\
\text { drinking water }\end{array}$ & 14.67 & 3.63 & 22.0 & 14.59 & 3.4 & 23.3 & 68.8 \\
\hline CASE 2 & 7 & 4 & 2 & 1 & $\mathbf{0}$ & $\begin{array}{c}\text { Irrigation \& } \\
\text { drinking, medium } \\
\text { flow }\end{array}$ & 16.63 & 4.12 & 25.0 & 16.48 & 4.2 & 27.3 & 63.3 \\
\hline CASE 3 & 7 & 4 & 2 & 1 & 1 & $\begin{array}{l}\text { I \& D, medium flow } \\
\text { and } 1 \text { dwelling }\end{array}$ & 29.13 & 7.21 & 43.8 & 28.40 & 7.2 & 46.8 & 63.7 \\
\hline CASE 4 & 7 & 4 & 2 & 1 & 4 & $\begin{array}{l}\text { I \& D, medium flow } \\
\text { and } 4 \text { dwellings }\end{array}$ & 66.63 & 16.49 & 100.1 & 64.22 & 16.8 & 109 & 61.7 \\
\hline CASE 5 & 12.8 & 9 & 2 & 1.8 & 0 & $\begin{array}{c}\text { Irrigation \& drinking, } \\
\text { higher flow }\end{array}$ & 28.78 & 7.13 & 43.3 & 28.05 & 6.9 & 51.3 & 65.7 \\
\hline CASE 6 & 12.8 & 9 & 2 & 1.8 & 1 & $\begin{array}{l}\text { I \& D, higher flow } \\
\text { and } 1 \text { dwelling }\end{array}$ & 41.28 & 10.22 & 62.0 & 40.27 & 10.2 & 66.3 & 63.7 \\
\hline CASE 7 & 12.8 & 9 & 2 & 1.8 & 4 & $\begin{array}{l}\text { I \& D, higher flow } \\
\text { and } 4 \text { dwellings }\end{array}$ & 78.78 & 19.50 & 118.4 & 76.83 & 19.8 & 124 & 62.8 \\
\hline
\end{tabular}


As indicated above, only cases 2, 3 and 6 have been considered relevant for further analysis. Case 2 is the base example for irrigation and drinking water. In Case 3, the system produces the same amount of water, but electricity is provided to the site dwelling. Case 6 keeps the variable for drinking water and electricity the same but increases the water for irrigation.

\section{Economic Analysis}

For Case 2, the estimated costs (although information from suppliers and several sources has been consulted for the costs, assumptions have been made for the length of project, inflation and operation costs) of the current scenario of diesel pumps and obtaining drinking water from Meharrize (a) have been compared with introducing a PV based system (b):

(a) The cost of the diesel pumps and drinking water for a lifetime of 25 years, including fuel, maintenance and installation for irrigation, has been estimated at 92,140 euros without inflation and 172,572 euros with $5 \%$ inflation, mainly due to the cost of the water-This estimate assumes that $20 \%$ of the water is drawn from the river without cost, and $80 \%$ of the water is purchased at a cost of $4.5 € / \mathrm{m}^{3}$.

(b) The cost of the PV panels, solar pump, desalination units, batteries, controller, inverter and rest of the PV-BWRO system (Case 2) for 25 years, including transport, installation, commissioning, maintenance and security (to prevent theft or vandalism), has been estimated at 55,723 euros without inflation and 74,102 euros with 5\% inflation, with an initial investment of 35,491 euros.

For the payback calculation of the PV-BWRO system, the net annual cash flows have been calculated comparing the life cycle costs (LCC) of these two scenarios (diesel pumps and obtaining drinking water in Meharrize, and Case 2 solar PV system). The simple payback (SPB) without inflation and considering the first year as reference is 11.8 years. The payback $(\mathrm{PB})$ with inflation and considering all net annual cash flows is 10.1 years. The net present value (NPV) with a discount rate $i$ of 0.05 over years is 26,887 euros (the discount rate is the return that could be earned on an investment with similar risk), which means that the investment is profitable (NPV $>0$ ) with the indicated conditions and assumptions. The internal rate of return (IRR) is 0.1041 (10.41\%), which means that with a discount rate of up to $10 \%$, the project still is profitable. Indeed, according to [20] a renewable energy water pumping solution outperforms the costs of a diesel water pumping system. Additionally, it must be highlighted that the current case (a), using diesel pumps does not provid water suitable for irrigation. The cost of electricity was not a factor because the system costs are for an off-grid application [13]. The benefits from the salt have not been taken into account, but depending on their characteristics they could have a positive impact in the economic analysis. The lifecycle emissions of 
the PV system have been roughly estimated at $13.4 \mathrm{tCO}_{2} \mathrm{eq}$, compared to $98.3 \mathrm{tCO}_{2}$ eq if a typical grid in Africa was used or $118.3 \mathrm{tCO}_{2}$ eq if using a diesel generator.

\section{Sensitivity Analysis}

A sensitivity analysis has been performed for Case 2, plotting NPV when changing the discount rate $i$, inflation, the fuel cost and the water cost. A similar approach was taken by [13]. Decreasing the discount rate from 0.1 to 0 transforms the project from an unprofitable one into a very profitable one, as shown in Figures 5 and 6. Inflation does not affect the investment, but it affects all prices from the first year. Thus, the impact of inflation on the NPV is significant, especially when it is above $5 \%$. Without inflation NPV is close to 0 . The study also showed that the drinking water cost is much more important than the fuel cost in the economic analysis, as shown by comparing the slopes of the curves in Figures 7 and 8 .

\section{NPV (Net Present Value) vs i (discount rate)}

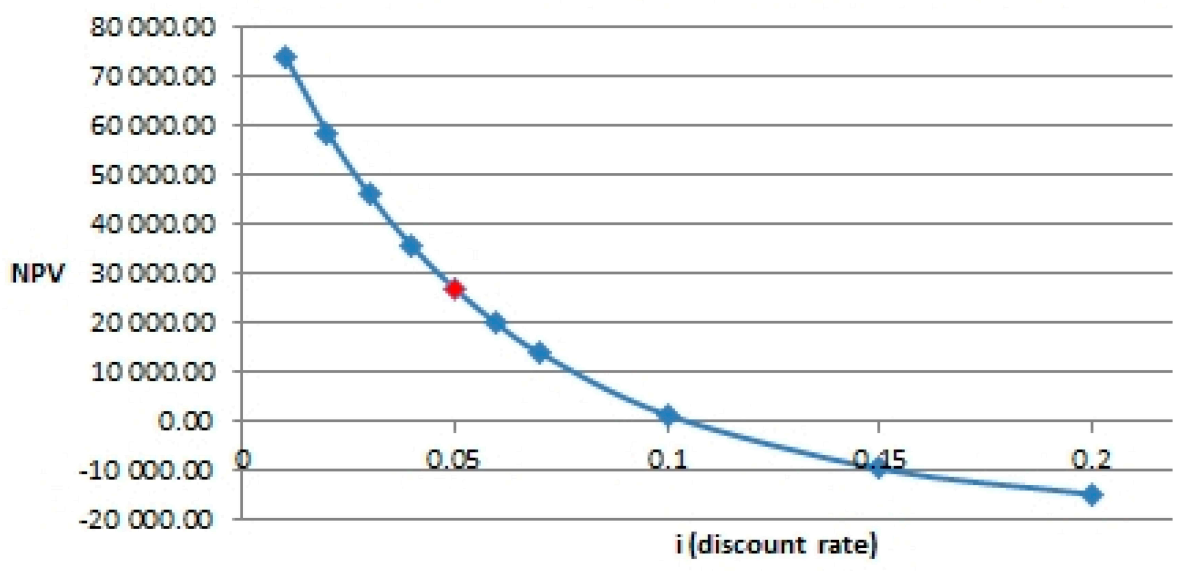

Figure 5. Sensitivity analysis NPV-discount rate.

NPV (Net Present Value) vs inflation

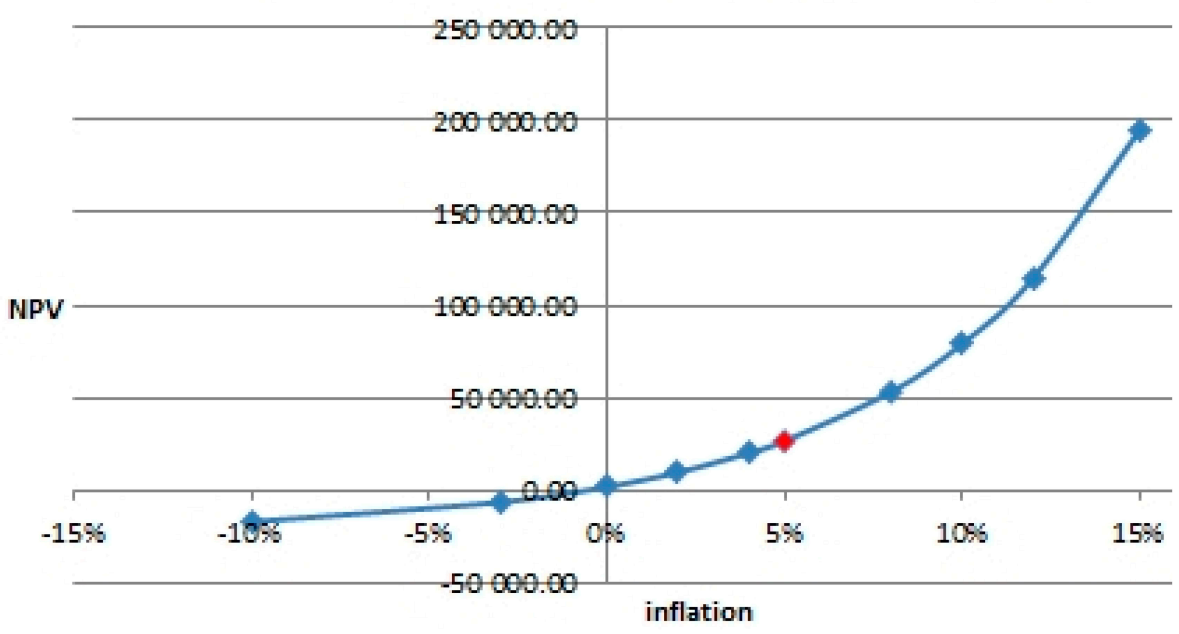

Figure 6. Sensitivity analysis NPV-inflation rate. 


\section{NPV (Net Present Value) vs fuel cost}

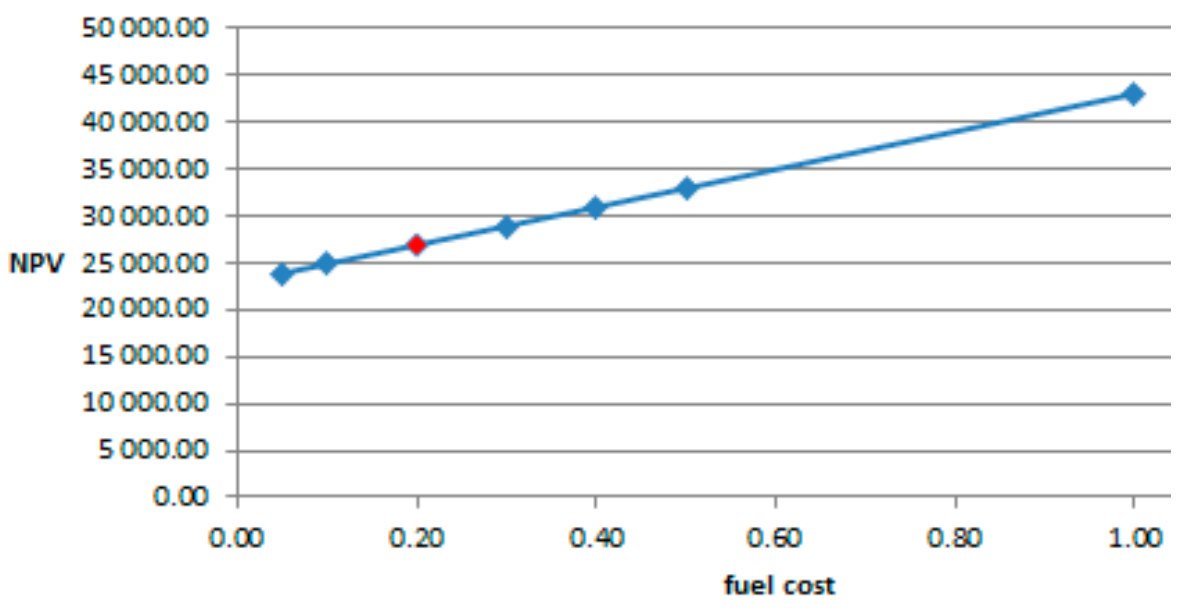

Figure 7. Sensitivity analysis NPV-fuel cost.

\section{NPV (Net Present Value) vs water cost}

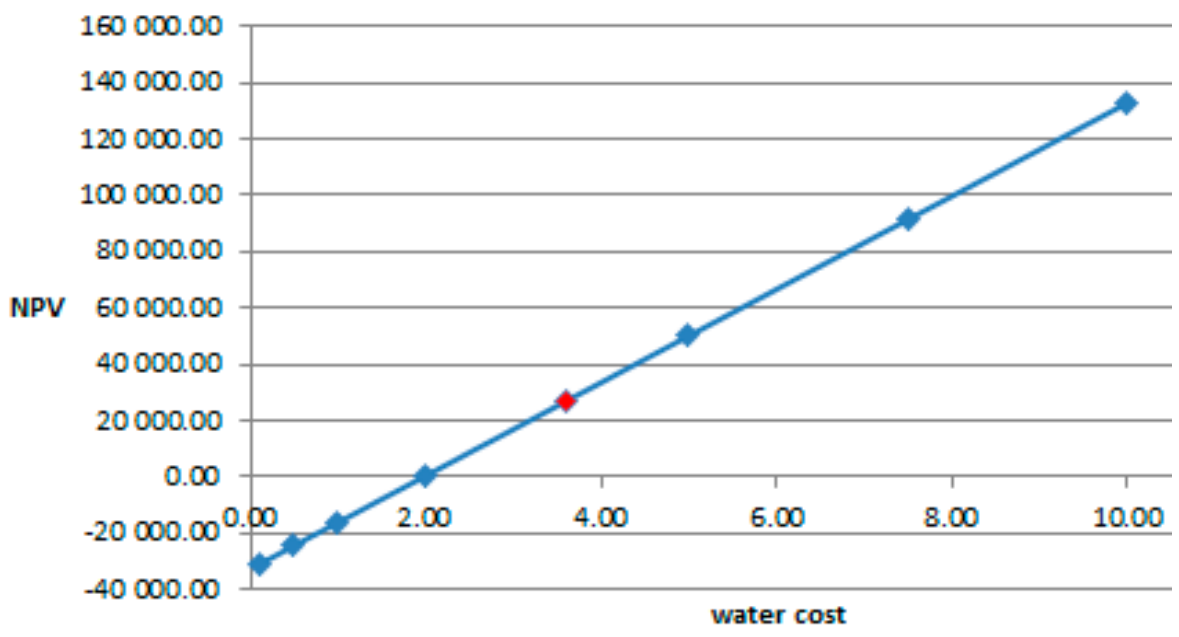

Figure 8. Sensitivity analysis NPV-water cost.

\section{Alternative Cases: Additional Consumption (Case 3) and Additional Water Flow (Case 6)}

In Case 3, the electric power consumption of one dwelling has been included. Because the designed system is able to provide AC electricity and to store solar energy in batteries, the size of the PV array can be increased to take advantage of the opportunity to use it for domestic consumption, thus saving money compared to building a bespoke new off-grid installation. The daily consumption of one dwelling has been estimated at $12.5 \mathrm{kWh}$, including consumption by a refrigerator, TV and/or computer, washing machine, air conditioning, lights and microwave oven/kettle. Heating is not needed, and gas cylinders are normally used for cooking main meals. The total energy consumption $E_{T}$, including the solar pump and the desalination units is $29.13 \mathrm{kWh}$ per day. Similarly, as with Case 2, a subsystem efficiency $\eta_{s}$ of 0.80 , from Equation (3) was used so the daily 
energy demand $E_{e}$ is $36.4 \mathrm{kWh}$. From Equation (8), if PR is 0.85 and the averaged daily solar radiation on the PV array surface $H_{T}$ is $5.94 \mathrm{kWh} / \mathrm{m}^{2}$, then the PV array power P is $7.21 \mathrm{kWp}$. Alternatively, from Equation (9), if PSSH is $5.94 \mathrm{~h}, F_{t h}$ is 0.83 , the battery efficiency $\eta_{b}$ is 0.90 and the inverter efficiency $\eta_{i n v}$ is 0.90 , then the PV array power $\mathrm{P}$ is $7.29 \mathrm{kWp}$. From Equation (4), if the conversion efficiency $\eta_{p v}$ is 0.14 , then the area $A_{p v}$ can be roughly estimated as $43.8 \mathrm{~m}^{2}$, which is an increase of $75 \%$ over the base Case 2. The NPV for Case 3 is 17,147 euros, so it is still profitable with the same conditions (25 years, $i=0.05$, inflation $5 \%$ ). The NPV is lower than the base case because the additional generated electricity has not been included in the economic analysis (the electricity generation for the dwelling consumption could have been compared with the cost of generating electricity with a diesel generator, but this scenario seems not to be a realistic one because, according to the local contact, PV panels are normally used in new installations). However, the cost of this additional electricity will be definitely lower than for a new installation.

Another variation has been analysed in Case 6 where the irrigation volume was increased from 4 to $9 \mathrm{~m}^{3}$ in order to substantially extend the crop area. The total energy required is $41.28 \mathrm{kWh}$ per day with $P$ rated at $10.22 \mathrm{kWp}$, and $A_{p v} 62 \mathrm{~m}^{2}$. The NPV for this case is still positive but is much lower than in the base case because the added value of irrigation is not considered in the analysis (the economic value added to the irrigation could be calculated based on the produced food and the generated salt, but this calculation is beyond the scope of this work.).

The choice between Case 2 (base case) and Case 3 depends on the funding and subsidies for the initial investment. However, in principle, it seems reasonable to consider the consumption of one dwelling, taking into account the costs saved compared to building a separate installation for the house. Regarding Case 6, the available sizes and prices of the RO should be double checked in order to make a decision, provided that the funding allows it. There are some other potential improvements related to the control system such as tracking PV modules or moisture sensors/probes and automatic valves at the outlet of the irrigation tank [34,35]. Furthermore, utilising IoT monitoring and management could improve resource use and reduce costs, for example as demonstrated for irrigation in [36].

\section{CONCLUSIONS}

This project shows the details and feasibility of a system capable of providing water for both irrigation and drinking, as well as electricity, in desert areas for many years with a reasonable investment to meet sustainable development goals. The study has met the objectives set out in the introduction. The water resource assessment was considered sufficient for the design, but it should be verified in terms of quality and quantity. The salinity was assessed at $11 \mathrm{~g} / \mathrm{L}$. Based on the energy resource assessment and review of suitable technologies, PV solar energy has been 
determined to be a suitable technology for water pumping, desalination, and additional electricity generation $[11,16,19]$. The main water and power requirements in the project area have been identified. The need to be flexible in the design led to several scenarios being considered in the study. A model, PV-BWRO, to provide water and electricity, based on solar pumps and PV power" has been designed and evaluated. After analysis of the different scenarios, one case with $4 \mathrm{~m}^{3}$ of water for irrigation and $2 \mathrm{~m}^{3}$ for drinking water was proposed for implementation. $1 \mathrm{~m}^{3}$ of brine was also produced. The economic analysis of the model shows the savings of the selected case compared to a scenario utilising diesel pumps. Finally, a sensitivity analysis has been performed to evaluate the impact of changing certain variables with four of the most significant presented in Figures 5-8.

Additionally, two variations of the design have been presented: One with electricity generation for one dwelling and the other with higher flow rates for irrigation $\left(9 \mathrm{~m}^{3}\right)$. The decision to adopt these alternative systems would mainly depend on funding. The size of the PV array can be increased to provide electricity for more consumers, but the system would need to be analysed to verify that all elements are suitable for doing so. There are also some possible improvements and alternatives for further research, such as tracking panels, automatic valves and the use of IoT [36]. This project is reproducible and scalable, but a proper analysis of water and well characteristics wold be required in advance. The use of the salts from brine also should be defined. If the system were grid-connected, then excess electricity could potentially provide a revenue stream, depending on tariffs. [37]. Further areas for research could include using grey water from the drinking supply for irrigation and the potential to grow crops between rows of PV modules where larger solar irrigation systems are deployed [38-40].

\section{DATA AVAILABILITY}

Data generated from the study is available in the supplementary file.

\section{SUPPLEMENTARY MATERIAL}

The supplementary material is available online at https://doi.org/10.20900/jsr20200018.

\section{AUTHOR CONTRIBUTIONS}

JI and RB designed the study. JI developed the model and analyzed the data with input from RB. JI and RB wrote the paper.

\section{CONFLICTS OF INTEREST}

The authors declare that there is no conflict of interest. 


\section{ACKNOWLEDGEMENTS}

The authors of this paper would like to express their gratitude and sincere appreciation to Louali Salem Douh for his confidence in this research and for providing valuable data and information about the project site.

\section{REFERENCES}

1. ENID (Egypt Network for Integrated Development). Solar Water Pumps: The Case of Egypt's Desert, Case Study 013. 2013. Available from: http://www.enid.org.eg/uploads/pdf/CS13 solar water pumps.pdf. Accessed 2016 Aug 5.

2. IRENA (The International Renewable Energy Agency). Solar pumping for irrigation: Improving livelihoods and sustainability. Abu Dhabi (United Arab Emirates): IRENA; 2016.

3. Burney J, Woltering L, Burke M, Naylor R, Pasternak D. Solar-powered drip irrigation enhances food security in the Sudano-Sahel. Proc Natl Acad Sci U S A. 2010;107(5):1848-53.

4. Phiri E, Rowley P, Blanchard R. The feasibility of solar water-pumping in a rural village of Malawi. Presented at the First International Conference on Solar Energy Solutions for Electricity and Water Supply in Rural Areas; 2015 Oct 7-10; Cairo, Egypt.

5. Shinde VB, Wandre SS. Solar photovoltaic water pumping system for irrigation - A review. Afr J Agric Res. 2015;10(22):2267-73.

6. Moumakwa NL, Nan P, Johnson L. Application of Solar Powered Irrigation Systems in Botswana. Presented at the 4th SASEC (Southern African Solar Energy Conference); 2016 Oct 31-Nov 2; Stellenbosch, South Africa.

7. Phiri E, Rowley P, Blanchard R. Meeting the water and energy needs in the rural areas of Malawi using solar PV technologies. Presented at the 40th WEDC International Conference; 2017 Jul 24-8; Loughborough, UK.

8. Hussain M, Blanchard R. Developing a low cost solar powered water pump for deployment in developing nations for agricultural purposes. Presented at the 40th WEDC International Conference; 2017 Jul 24-8; Loughborough, UK.

9. Wydra K, Becker P, Aulich HA. Sustainable solutions for solar energy driven drinking water supply for rural settings in Sub-Saharan Africa: a case study of Nigeria. J Photonics Energy. 2019;9(4):043106. https://doi.org/10.1117/1.JPE.9.043106

10. Wydra K, Jaskolski M, Wagner L, Mohamed ES. Nexus approach to solar technology for energy and water supply for sustainable rural development in Egypt: a review. J Photonics Energy. 2019;9(4):043108. https://doi.org/10.1117/1.JPE.9.043108

11. Dana B. Small Scale Offgrid PV: Installation Manual. Rugby (UK): Quetsol S.A.; 2012.

12. Razmjoo A, Shirmohammadi R, Davarpanah A, Porfayaz F, Aslani A. Standalone hybrid energy systems for remote area power generation. Energy Rep. 2019;5:231-41. 
13. Ayodele E, Misra S, Damasevicius R, Maskeliunas R. Hybrid microgrid for microfinance institutions in rural areas - A field demonstration in West Africa. Sustain Energy Technol Assess. 2019;35:89-97.

14. Youssef PG, Al-Dadah RK, Mahmoud SM. Comparative analysis of desalination technologies. Energ Proc. 2014;61:2604-7.

15. Mazraeh AE, Babayan M, Yari M, Sefidan AM, Saha SC. Theoretical study on the performance of a solar stil system integrated with PCV-PV module for sustainable water and power generation. Desalination. 2018;442:184-97.

16. Thomson M. Reverse-Osmosis Desalination of Seawater Powered by Photovoltaics Without Batteries [dissertation]. Loughborough (UK): Loughborough University; 2003.

17. Bermudez-Contreras A, Thomson M, Infield DG. Renewable energy powered desalination in Baja California Sur, Mexico. Desalination. 2008;220:431-40.

18. WHO. Guidelines for Drinking-water Quality. 4th ed. Geneva (Switzerland): WHO; 2011.

19. Argaw N. Renewable Energy Water Pumping Systems Handbook; Period of Performance: April 1--September 1, 2001. Golden (CO, US): NREL; 2004.

20. Cloutier M, Rowley P. The feasibility of renewable energy sources for pumping clean water in sub-saharan Africa: a case study for Central Nigeria. Renew Energy. 2011;36(8):2220-6.

21. Ratterman W, Cohen J, Garwood A. Green Empowerment Solar Pumping Systems (SPS) Introductory and Feasibility Guide. Portland (OR, US): Green Empowerment; 2003. Revised in 2007.

22. Noble N. Solar PV Water pumping. Rugby (UK): Practical Action; 2010. Available from: https://answers.practicalaction.org/our-resources/item/solarphotovoltaic-water-pumping. Accessed 2019 Oct 1.

23. Chandel SS, Nagaraju NM, Chandel R. Review of solar photovoltaic water pumping system technology for irrigation and community drinking water supplies. Renew Sustain Energy Rev. 2015;49:1084-99. https://doi.org/10.1016/j.rser.2015.04.083

24. Wazed SM, Hughes BR, O'Connor D, Calautit JK. A review of sustainable solar irrigation systems for Sub-Saharan Africa. Renew Sustain Energy Rev. 2017;81:1206-25. https://doi.org/10.1016/j.rser.2017.08.039

25. Al-karaghouli A, Kazmerski LL. Comparisons of Technical and Economic Performance of the Main Desalination Processes With and Without Renewable Energy Coupling. Presented at the World Renewable Energy Forum; 2012 May 13-7; Denver, CO, USA.

26. Industry News - Solar Desalination: A Sunrise Sector. 2016. Available from: http://industrynews.co/index.php/2016/08/29/solar-desalination-a-sunrisesector/. Accessed 2016 Aug 7.

27. Clayton ME, Stillwell AS, Webber ME. Implementation of brackish groundwater desalination using wind-generated electricity: A case study of the energy-water nexus in Texas. Sustainability. 2014;6(2):758-78.

28. Sarai Atab M, Smallbone AJ, Roskilly AP. An operational and economic study of a reverse osmosis desalination system for potable water and land irrigation. Desalination. 2016;397:174-84. 
29. Frenken K, Faurès JM. Irrigation Potential in Africa: A Basin Approach. Rome (Italy): FAO; 1997.

30. NASA. NASA Surface meteorology and Solar Energy - Choices. 2017. Available from: https://eosweb.larc.nasa.gov/cgi-bin/sse/grid.cgi?email=skip\%40larc. nasa.gov\&step=1\&lat=26.172147\&lon=-11.0875829\&submit=Submit. Accessed 2017 Mar 5.

31. PVGIS and European Comission Joint Research Centre - Renewable Energies Unit. Photovoltaic Geographical Information System - Interactive Maps. 2017. Available from: http://re.jrc.ec.europa.eu/pvgis/apps4/pvest.php?lang=en\& map=africa. Accessed 2019 Sep 28.

32. "PVsyst" Photovoltaic Software. Geneva (Switzerland): PVsyst S.A.; 2017.

33. Earthwise. British Geological Survey. Hydrogeology of Morocco \& Western Sahara (Moroccan Sahara). 2017. Available from: http://earthwise.bgs.ac.uk/ index.php/Hydrogeology of Morocco \%26 Western Sahara (Moroccan Sah ara). Accessed 2017 Mar 5.

34. Abdelkerim AI, Eusuf MMRS, Salami MJE, Aibinu A, Eusuf MA. Development of Solar Powered Irrigation System. IOP Conf Ser Mat Sci Eng. 2013;53(1):012005.

35. Harishankar S, Kumar RS, Sudharsan KP, Vignesh U, Viveknath T. Solar Powered Smart Irrigation System. Adv Electron Electr Eng. 2014;4(4):341-6.

36. Adenugba F, Misra S, Maskeliunas R, Damadevicius R, Kazanavicius E. Smart irrigation system for environmental sustainability in Africa: An Internet of Everything (IoE) approach. Mathemat Biosci Eng. 2019;16(5):5490-503.

37. Ghenai C, Merabet A, Salameh T, Pigem EC. Grid-tied and stand-alone power systems for desalination pant. Desalination. 2018;435:172-80.

38. Hassanpour AE, Selker JS, Higgins CW. Remarkable agrivoltaic influence on soil moisture, micrometeorology and water-use efficiency. PLoS ONE. 2018;13(11):e0203256. https://doi.org/10.1371/journal.pone.0203256

39. Adeh EH, Good SP, Calaf M, Higgins CW. Solar PV Power Potential is Greatest Over Croplands. Sci Rep. 2019;9:11442. https://doi.org/10.1038/s41598-01947803-3

40. Ravi S, Macknick J, Lobell D, Field C, Ganesan K, Jain R, et al. Colocation opportunities for large solar infrastructures and agriculture in drylands. App Energy. 2016;165:383-92.

How to cite this article:

Izquierdo J, Blanchard RE. Solar Desalination System Design for Irrigation/Drinking Water and Electricity Generation in Desert or Arid Areas. J Sustain Res. 2020;2(2):e200018. https://doi.org/10.20900/jsr20200018 